Chirurgia (2021) 116: 533-541

No. 5, September - October

Copyright $\odot$ Celsius

http://dx.doi.org/10.21614/chirurgia.116.5.533

\title{
Sentinel Lymph Node Biopsy in Breast Cancer. Principle, Difficulties and Pitfalls
}

\author{
George lancu ${ }^{1,2}$, Laura M. Mustata ${ }^{2}$, Ruxandra Cigaran'2, Nicolae Gica ${ }^{1,2}$, Radu Botezatu ${ }^{1,2}$, Dragos Median², \\ Anca Maria Panaitescu ${ }^{1,2}$, Gheorghe Peltecu ${ }^{1,2^{*}}$
}

${ }^{1}$ Carol Davila University of Medicine and Pharmacy, Bucharest, Romania.

${ }^{2}$ Filantropia Clinical Hospital, Bucharest, Romania

*Corresponding author:

Professor Gheorghe Peltecu

Filantropia Clinical Hospital

11-13 Blvd. Ion Mihalache

11171-Bucharest, Romania

E-mail: gheorghe.peltecu@gmail.com

\section{Rezumat \\ Biopsia de ganglion santinelă în cancerul mamar. Principii, dificultăți si capcane}

Biopsia de ganglion santinelă reprezintă abordarea standard în cancerul mamar incipient, ca tehnică comună pentru stadializarea axilară. Aceasta reprezintă un factor de prognostic important în diagnosticul cancerului mamar şi ghidează ulterior tratamentul chirurgical şi cel oncologic. Deşi mulți ani la rând s-a utilizat limfodisecția axilară standard ca metodă de stadializare pentru cancerele mamare, această metodă a fost înlocuită cu tehnica identificării şi exciziei ganglionului santinelă pentru a reduce riscul de limfedem, infecție, leziuni ale nervilor sau vaselor axilare şi a pentru a diminua impactul funcțional asupra mobilității brațului şi umărului. Acest lucru s-a tradus într-o îmbunătățire semnificativă a calității vieții pacientelor diagnosticate cu cancer mamar incipient. Principiul ganglionului santinelă se bazează pe ipoteza că modul drenajului celuleor maligne în cancerul mamar se face ordonat şi s-a dovedit că dacă biopsia ganglionului santinelă este negativă pentru metastază, atunci şi restul bazinului limfatic axilar este neafectat de cancerul mamar. În lucrarea prezentată am detaliat atât indicațile ganglionului santinelă, cât şi posibilele dificultăți şi capcane întâlnite în practica uzuală a identificării sale.

Cuvinte cheie: cancer mamar, biopsie ganglion santinelă, cancer mamar incipient, limfodisecție axilară 


\section{Abstract}

Sentinel Lymph node biopsy (SLNB) represents the standard approach in a newly diagnosed breast cancer for axillary staging in cases of clinical node negative. This represents a major prognostic factor and the biopsy of sentinel lymph node for early breast cancer is used as guidance in surgical and oncological treatment. Although for many decades, axillary lymph node dissection was the standard approach for breast cancer treatment and staging, this pathway was abandoned due to significant risk of lymphedema, infection, nerve and vessels injury or dysfunction of the shoulder. Therefore, significant improvement in the quality of life was seen for patients diagnosed with early breast cancer after SLNB was introduced as standard. The principle of SLNB is based on the hypothesis that tumor drains in the lymphatic system in an orderly manner and if the first lymphatic station is clear of disease, it is highly unlike that the tumor has spread further above. We present in our paper the indications with principles and difficulties in identification of sentinel node.

Key words: breast cancer, sentinel lymph node biopsy, SLNB, ALND, early breast cancer

\section{Introduction}

Axillary lymph nodes are the main route of breast lymphatic drainage and the most common site of locoregional spread of breast carcinoma. The status of axillary lymph nodes is an important prognostic factor in the management of breast cancer.

Historically, the axillary lymph nodes were considered the main lymphatic basin of the breast and a secondary source of spreading of a breast cancer. In the seventh decade of the last century Fisher $(1,2)$ and Veronesi $(3,4)$, independently, launched a new paradigm of breast cancer based on clinical and laboratory studies, changing the old concept founded by Halsted, based on Virchow's theory of cancer (5). According to the new paradigm, breast cancer was a systemic disease from the beginning, before being clinically diagnosed, and the local surgical treatment will not improve survival with increased radicality. A more conservative approach towards breast cancer surgical treatment concerning in lumpectomy was proposed, despite initially increased resistance of the medical body. Patient survival and metastases occurrence was rather an expression of biological characteristics and relationship between host and tumor (1). So, axillary lymph node dissection (ALND) became a part of the conservative treatment of early breast cancer. Later on, sentinel lymph node biopsy (SLNB) was standardized and widely adopted in breast cancer guidelines, as accurate image of the entire nodal basin, after it was first introduced by Giuliano and Krag in early '90s $(6,7)$. Gradually, routine ALND in breast cancer was replaced by sentinel lymph node technique as a standard of care and was completed with full ALND when sentinel lymph node(s) had metastases. The main advantage was a significantly lower morbidity associated with SLNB compared to ALND $(8,9)$.

\section{Principle}

The sentinel lymph node is the first lymph node draining a certain area of the breast, including the tumor bed. It is therefore the first lymph node involved in metastatic disease and its biopsy and pathology assessment could avoid axillary lymph node full dissection in patients with negative findings. The concept of sentinel node biopsy was increasingly accepted in oncological surgery as a standard of care in staging axilla in early breast cancer, decreasing the associated morbidity (10-12). 
Lymphatic mapping techniques for the breast used radioactive colloids, dyed agents or both. Although initially localization agents were injected intra, sub or peritumoral, currently they are injected mainly periareolar or subareolar, intradermal or subdermal, with very good sensitivity for axillary SLN identification $(13,14)$. Internal mammary lymph nodes are not routinely evaluated due to technical difficulties of harvesting, their rare involvement when axilla is negative and low risk of recurrence. Around 5-10\% false negative rate for SLNB procedure is reported in the literature, but sensitivity of the procedure over $95 \%$ is also cited $(12,15,16)$.

\section{Indications}

According to current guidelines, SLNB is the standard for axillary staging in early breast cancer patients ( $\mathrm{T} 1, \mathrm{~T} 2)$, in the management of clinically negative axilla (17). Ultra-staging the sentinel node(s) (additional sectioning, immunohistochemistry (IHC) or polymerase chain reaction $(\mathrm{PCR})$ ), is not routinely recommended, hematoxylin and eosin (HE) staining being the standard assessment tool (18). The role of isolated tumor cells, micrometastases or oligometastases on changing patient outcome or surgical management is still debatable (19).

\section{Axillary management when negative SLNB}

Large randomized clinical trials clearly confirmed the safety of appropriately staged axilla with SLNB alone, sparing axillary lymph node dissection, when SLNB is negative. There was no adverse impact on local recurrence, disease-free survival, or overall survival when SLNB alone versus SLNB followed by ALND were compared, when SLNB was negative. Postoperative arm morbidity was significantly lower after SLNB alone, compared with ALND (10,11,12,20). Currently, negative SLNB is sufficient, safe and efficacious for axillary staging in patients with early breast cancer and clinically negative axilla, making it a standard of care for this group of breast cancer patients.

\section{Axillary management when positive SLNB}

The clinical situation of positive SLNB on pathology is still under debate. There is an increasing evidence that the presence of low burden metastatic disease in SLN (occult micrometastases) have negligible effect on patients' outcome and ultra-staging to detect SLN micrometastases is not routinely recommended $(19,21,22)$. When SLNB is positive on HE staining (macrometastases), ALND is recommended when no further whole-breast radiotherapy is planned, more than 2 nodes are involved or no preoperative chemotherapy was delivered (22).

\section{SLNB in clinically positive axilla}

Clinically positive axilla should be assessed by fine needle aspiration or core needle biopsy of the suspected nodes. If positive axillary nodes are found, standard ALND (level I and II) should be undertaken (22). However, there is increasing evidence for the safe management of the axilla (1-3 positive SLN) without ALND, in the presence of locoregional radiotherapy and/or systemic chemotherapy.

\section{Other Indications}

\section{Neoadjuvant chemotherapy}

Neoadjuvant chemotherapy (NACT) prescribed before axillary surgical staging could confound pathological information obtained otherwise, possibly by changing the status of SLN. However, the status of SLN in this circumstance, usually, does not influence the decision of recommending systemic treatment. Additionally, SLNB before neoadjuvant chemotherapy is debatable because it cancels the possibility of revealing downstaging axillary effect of NACT. Biopsy of suspicious nodes under ultrasound control and marking positive nodes with clips for future removal is an alternative for correct axillary assessment. On the other hand, SLNB before NACT helps in establishing the need for subsequent axillary radiotherapy, especially when SLNB is negative, but does not quantify the burden of disease when SLNB is positive. 
The need for locoregional therapy is currently based on other independent predictors of recurrence, like tumor size, nodal status at presentation or response to NACT (23). Sentinel lymph node biopsy seems to be a reliable option for axillary staging in patients treated with neoadjuvant chemotherapy (24).

\section{DCIS}

Ductal carcinoma in situ usually does not require axillary staging because it does not infiltrate lymphatics and does not metastasize. Invasive carcinoma has been reported to represent $10-20 \%$ of all specimen removed after a diagnostic biopsy of DCIS (25). Ductal carcinoma in situ with an area of suspicion larger $>5 \mathrm{~cm}$ or DCIS associated with a palpable mass has a higher risk of invasive disease. In patients with extensive DCIS requiring mastectomy or wide local excision followed by oncoplastic procedures, both disrupting lymphatics, SLNB is usually indicated because of the increased probability of invasive disease on final specimen at pathology $(21,26,27)$.

\section{Multicentric Breast Cancer}

Although patients with multicentric breast cancer were frequently excluded from clinical trials, it was clearly proved subsequently that most of breast areas drain the lymph towards axillary nodes irrespective of the site of tracer injection and SLNB is an effective and safe procedure for axilla staging in multicentric breast cancer patients $(14,21$, $28,29,30,31,32)$. Sentinel lymph node biopsy was successfully performed in most studies evaluating multicentric breast cancer patients, the rate of false negative results being $4 \%(31,32,33)$. The likelihood of finding more metastases in the axillary lymph nodes is higher in multicentric disease.

\section{Prophylactic mastectomy}

Prophylactic mastectomy is usually undertaken by patients at high risk of developing breast cancer, with BRCA oncogenic mutations or with family history of hereditary breast or ovarian cancer or contralateral breast cancer. It is cited an incidence of about $3-5 \%$ of occult breast cancer in these patients (34). However, only a very small proportion of this subpopulation has positive SLNB, therefore routine SLNB evaluation in patients with prophylactic mastectomy is not recommended.

\section{Previous breast surgery}

Patients with previous breast or axillary surgery usually have lymphatic pathways disrupted with aberrant drainage developed and part of lymph nodes or SLN excised in previous procedures. In these circumstances, SLNB procedure has lower efficacy and safety. A recent meta-analysis of over 12,000 patients with breast cancer, that had radical or conserving breast surgery, revealed an average loco-regional recurrence rate of $7.9 \%$, with a rate of $7.1 \%$ after breast conserving surgery and $8.9 \%$ after mastectomy (35). Axillary lymph node dissection in patients with loco-regional recurrences revealed that the vast majority of these patients with clinically negative axilla $(76 \%)$ did not have any positive nodes on pathology, questioning the opportunity of the procedure in these subpopulation (36). Sentinel node identification rate in patients with previous axillary surgery was evaluated in a recent metaanalysis comprising of 692 patients; SLN identification rate was on average $65.3 \%$, significantly higher in patients with previous SLNB compared with previous ALND (81\% vs. $52.2 \%$ ). The results were mainly the consequence of aberrant lymphatic pathways developed after ALND (37).

However, SLNB in patients with recurrent breast cancer can be considered and dual mapping technique can be recommended to increase identification rate of SLN; the benefit on long term survival is still under research.

\section{Contraindications}

Sentinel lymph node biopsy is contraindicated in case of clinically positive axilla, in locally 
advanced disease and inflammatory breast cancer.

\section{Clinically positive lymph nodes}

If clinical examination reveals palpable lymph nodes, these have to be explored by fine-needle aspiration (FNA) or core needle biopsy. If pathology examination shows malignancy, ALND is the standard recommendation.

\section{Locally advanced breast cancer and inflammatory breast cancer}

Two well recognized guidelines (American Society of Clinical Oncology, 2014, and International Expert Panel, 2010) do not recommend the use of SLNB in patients with locally advanced breast cancer or inflammatory breast cancer $(18,21,38)$. In these patients, ALND is recommended to maximize locoregional control (38).

Patients with locally advanced breast tumors involving the skin and/or the chest wall will not be taken into consideration for SLNB (39).

There are studies showing that even in patients with larger tumors (T3) and clinically negative axilla, SLNB could be accurate $(40,41)$. Therefore, tumor size larger than 5 $\mathrm{cm}$, with clinically negative axilla, should not be an absolute contraindication for SLNB procedure.

\section{SLNB Difficulties and Pitfalls}

Sentinel lymph node biopsy is a feasible, accurate and less morbid technique than ALND and is the standard approach for patients with early disease, identifying approximately $96 \%$ of patients $(16,42,43)$.

However, there are some difficulties and pitfalls.

\section{Size of metastases}

Sentinel lymph nodes metastases are classified according to their volume in: isolated tumor cells (malignant cell clusters $<0.2 \mathrm{~mm}$ ); micrometastases (malignant cell clusters $>0.2$ $\mathrm{mm}$ but $<2.0 \mathrm{~mm}$ ); occult micrometastases (malignant deposits found in SLN on IHC staining with cytokeratin); macrometastases (metastatic deposits $>2.0 \mathrm{~mm}$ ).

The standard evaluation of SLN is using $\mathrm{HE}$ staining. Immunohistochemistry staining with cytokeratin and deeper analysis or ultrastaging of SLN is currently not routinely recommended.

Isolated tumor cells identified in SLN do not have any adverse impact on patient outcome.

Micrometastases in SLN appeared to negatively impact the prognosis of breast cancer patients, but do not influence recurrence rate. Patients with occult micrometastases do not have higher loco-regional or distant recurrence rate (10).

For one or two positive lymph nodes in women with early stage breast cancer undergoing breast conserving surgery and consequently adjuvant whole breast radiotherapy, there is no need for further ALND; the completion of axillary dissection is needed in patients without radiotherapy in the management plan $(36,44)$.

When there are at least three SLN involved or there is an extra-nodal metastatic extension, ALND is usually recommended as standard of care, for accurate staging and to improve local control (45).

Although initially only the number of involved lymph nodes was taken into account, more recently it is the tumor burden in each node that is important as well. The size of grossly positive lymph nodes is important, measured usually on sections made in the SLN and cut into $2 \mathrm{~mm}$ slices. Contiguous tumor cells form clusters that should be measured on greatest diameter. The estimated size of metastasis in a lymph node can be challenging when there are multiple clusters of metastatic cells, following a dispersed pattern.

The histologic features of metastases in SLN should have similar histology with primary tumor; if a different histology is found, the possibility of another undiagnosed breast tumor should be considered. Additionally, difficulties can be given by invasive carcinoma foci in the adipose tissue 
that can be mistaken for lymph nodes, perimetastatic stromal reaction included in metastasis size measurement or entirely replacement of a lymph node by a metastasis. Benign axillary lymph nodes inclusions (epithelial cysts, capsular nevi, endosalpingiosis or heterotopic mammary glands) are very rare and they should be considered only after definitive exclusion of metastasis (46).

Extracapsular extension is another parameter that should be described by the pathologist. It does not change the N-staging, but it is associated with higher risk of increased axillary disease burden, without an increase in locoregional recurrence rate or reduced survival $(47,48)$.

\section{Non-visualization/non-identification of sentinel node}

Although currently SLN is identified using a radio-labelled tracer and/or colorimetric techniques, there are about $2-4 \%$ of cases when SLN cannot be identified and subsequently retrieved $(49,50)$. Risk factors cited for failure of SLN identification are increased body mass, tumor not localized in the outer upper quadrant or non-visualization of SLN on lymphoscintigraphy (50). A low interest for ALND in patients with failed identification of SLN is suggested nowadays, after the results provided by Giuliani et al in 'Z0011' trial (51), although there is still controversy and there are guidelines recommending for ALND in this category (52).

When there is no uptake of radiocolloid tracer in the axilla, a couple of measures must be considered.

First, increased rate of SLN identification is usually achieved using dual agent injection technique. Double identification technique is usually recommended in settings with higher probability of false negative results (poor experienced team, prior breast/axillary surgery, neoadjuvant chemotherapy) (53). If the radioactive tracer was injected and a SLN cannot be identified, injection of blue dye increases the chances to identify the hot spot. Additionally, if the tracer was injected only intraparenchimal, small intradermic injection increases the drainage towards the axilla with small radioactivity diffusion. Instillation of $10-40 \mathrm{~mL}$ saline at the place of radioactive tracer injection can sometimes increase the tissue pressure and the passage of the radiotracer into the lymph drainage system. If there is still difficult to locate SLN, then the surgeon should proceed anyway to skin incision at the base of axilla (under axillary hair line insertion) and reassess deeper with gamma probe. If there is still no SLN found, then ALND or sampling should be considered (53).

\section{Involvement of internal mammary nodes}

In most cases, SLNs are located in the axilla independent of the location of the breast tumor, making them easily accessible. In about $20 \%$ of patients ( $19 \%$ to $25 \%)$, nonaxillary sentinel lymph nodes were objectivated (mainly internal mammary nodes); however, only $1.3 \%$ of cases had metastases limited to internal mammary nodes (38). Their removal is technically difficult and clinical trials failed to prove a survival benefit after internal mammary nodes excision (54). Usually, they are positive for medially located breast tumors, over $2 \mathrm{~cm}$ in diameter and positive axillary nodes and associated prognosis is poor $(55,56)$. However, increasing evidence of benefits of identification and sampling of internal mammary nodes on changing adjuvant treatment options and overall survival is currently evolving and internal mammary nodes biopsy might be reconsidered in the near future $(57,58)$.

There are trials citing the presence of extra-axillary sentinel lymph nodes, mainly internal mammary nodes, in up to $20 \%$ of patients, but only a minority of them had sentinel nodes only outside the axilla and the impact on the management was limited $(59,60)$. However, there is increasing evidence of the benefit of treating extra-axillary lymph nodes (internal mammary or subclavicular) with extended fields adjuvant radiotherapy, with increased disease-free survival and reduced breast cancer mortality $(61,62,63)$. 


\section{Pathological analysis of sentinel lymph node}

Sentinel lymph nodes may undergo intraoperative evaluation if the management of the patient will be influenced during the operation by the result of this procedure (64).

Intraoperative diagnosis of SLNs can be performed either by frozen section, intraoperative touch preparation techniques (imprint cytology), or a combination of the two (65-67). Intraoperative evaluation of the SLN by frozen section is known to be less accurate than HE permanent sections (68). Both frozen section and imprint cytology have been shown to be limited in their ability to detect micrometastases (66) and have a wide variety in sensitivity rates $(78 \%$ - overall sensitivity for frozen section examination and $63 \%$ - overall sensitivity for imprint cytology), while the specificity for both methods approaches 100\% (69). Compared to imprint cytology, intraoperative frozen section has the advantage of preservation of tissue architecture, including metastasis size, but with the loss of fatty nodal tissue and possible frozen section artefacts (67).

The main goal of sentinel lymph node examination is to detect macrometastases, because of the prognostic value, which has been well established (70). Various protocols of SLN examination combines multiple $\mathrm{HE}$ sections and cytokeratin IHC (64), but currently there is no consensus as to which is most cost-effective (65). The majority of micrometastases ( 0,2 and 2 $\mathrm{mm}$ ) can be properly identified by HE alone (71). Micro-metastases are differentiated from isolated tumor cells based on size $(<0,2)(72)$, immunohistochemical stains being performed to increase the likelihood of micro-metastases and isolated tumor cells detection (73).

Although there are no standardized protocols for intraoperative diagnosis of SLNs, surgeons often request an intraoperative frozen examination to avoid unnecessary axillary lymph node dissection and associated morbidity.

\section{Conclusions}

Axillary staging using SLNB is currently the standard procedure for early breast cancer patients with clinically negative axilla. Axillary dissection can be securely spared in patients without or with minimal SLNs metastatic involvement. The major advantage of the procedure is a significant reduction of the associated morbidity (hematoma, infection, lymphocyst, pain), with similar outcomes when compared with ALND. Although technically easy to perform, there are often difficulties and pitfalls that can make difficult the decision of an unexperienced surgeon. Managing them correctly involves multidisciplinary teamwork with permanent feedback and the effort to ensure similar outcomes with less morbidity.

\section{Conflict of Interest}

No one of the authors has conflict of interest disclosures to report.

\section{References}

1. Fisher B, Fisher ER. The biology of metastasis. In Davis JH, ed. Current Concepts in Surgery. New York:McGraw Hill; 1965. P. 321-351.

2. Fisher B, Redmond C, Fisher ER, M Bauer, N Wolmark, D L Wickerham, et al. Ten-year results of a randomized clinical trial comparing radical mastectomy and total mastectomy with or without radiation. N Engl J Med. 1985;312(11):674-81.

3. Veronesi U, Saccozzi R, Del Vecchio M, Banfi A, Clemente C, De Lena M, et I. Comparing radical mastectomy with quadrantectomy, axillary dissection, and radiotherapy in patients with small cancers of the breast. N Engl J Med. 1981;305(1):6-11

4. Veronesi U, Valagussa P. Inefficacy of internal mammary nodes dissection in breast cancer surgery. Cancer. 1981;47(1):170-5.

5. Halsted WS. The result of operations for the cure of cancer of the breast performed at the Johns Hopkins Hospital from June, 1889 to January, 1894. Johns Hopkins Hosp. Ann Surg. 1894;20(5):497-555.

6. Giuliano AE, Kirgan DM, Guenther JM, Morton DL. Lymphatic mapping and sentinel lymphadenectomy for breast cancer. Ann Surg. 1994;220(3):391-8; discussion 398-401.

7. Krag DN, Weaver DL, Alex JC, Fairbank JT. Surgical resection and radiolocalization of the sentinel lymph node in breast cancer using a gamma probe. Surg Oncol. 1993;2(6):335-9; discussion 340.

8. Purushotham AD, Upponi S, Klevesath MB, Bobrow L, Millar K, Myles JP, et al. Morbidity after sentinel lymph node biopsy in primary breast cancer: results from a randomized controlled trial. J Clin Oncol. 2005; 23(19):4312-21.

9. Langer I, Guller U, Berclaz G, Koechli OR, Schaer G, Fehr MK, et al. Morbidity of sentinel lymph node biopsy (SLN) alone versus SLN and completion axillary lymph node dissection after breast cancer surgery: a prospective Swiss multicenter study on 659 patients. Ann Surg. 2007; 245(3):452-61.

10. Krag DN, Anderson SJ, Julian TB, Brown AM, Harlow SP, Ashikaga T, et al. Technical outcomes of sentinel-lymph-node resection and conventional axillary-lymph-node dissection in patients with clinically node-negative breast cancer: results from the NSABP B-32 randomised phase III trial. 
Lancet Oncol. 2007:8(10):881-8.

11. Veronesi U, Paganelli G, Viale G, Luini A, Zurrida S, Galimberti V, et al. Sentinel-lymph-node biopsy as a staging procedure in breast cancer: update of a randomised controlled study. Lancet Oncol. 2006;7(12):983-90.

12. Mansel RE, Fallowfield L, Kissin M, Goyal A, Newcombe RG, Dixon JM, et al. Randomized multicenter trial of sentinel node biopsy versus standard axillary treatment in operable breast cancer: the ALMANAC trial. J Natl Cancer Inst. 2006:98(9):599-609.

13. Reitsamer R, Peintinger F, Rettenbacher L, Prokop E, Sedlmayer F. Subareolar subcutaneous injection of blue dye versus peritumoral injection of technetium-labeled human albumin to identify sentinel lymph nodes in breast cancer patients. World J Surg. 2003;27(12):1291-4.

14. Klimberg VS, Rubio IT, Henry R, Cowan C, Colvert M, Korourian S. Subareolar versus peritumoral injection for location of the sentinel lymph node. Ann Surg. 1999:229(6):860-4; discussion 864-5.

15. Ban EJ, Lee JS, Koo JS, Seho Park, Seung II Kim, Byeong-Woo Park. How many sentinel lymph nodes are enough for accurate axillary staging in t1-2 breast cancer? J Breast Cancer. 2011;14(4):296-300.

16. Albertini JJ, Lyman GH, Cox C, Yeatman T, Balducci L, Ku N, et al. Lymphatic mapping and sentinel node biopsy in the patient with breast cancer. JAMA. 1996;276(22):1818-22.

17. Senkus E, Kyriakides S, Penault-Llorca F, Poortmans $P$, Thompson A, Zackrisson S, et al. Primary breast cancer: ESMO Clinical Practice Guidelines for diagnosis, treatment and follow-up. Ann Oncol. 2013;24 Suppl 6:vi7-23.

18. Kaufmann M, Morrow M, von Minckwitz G, Harris JR, Biedenkopf Expert Panel Members. Locoregional treatment of primary breast cancer: consensus recommendations from an International expert panel. Cancer. 2010;116(5):1184-91.

19. Giuliano AE, Hawes D, Ballman KV, Whitworth PW, Blumencranz PW, Reintgen DS, et al. Association of occult metastases in sentinel lymph nodes and bone marrow with survival among women with early-stage invasive breast cancer. JAMA. 2011;306(4):385-93

20. Ashikaga T, Krag DN, Land SR, Julian TB, Anderson SJ, Brown AM, et al. Morbidity results from the NSABP B-32 trial comparing sentinel lymph node dissection versus axillary dissection. J Surg Oncol. 2010;102(2):111-8.

21. Lyman GH, Temin S, Edge SB, Newman LA, Turner RR, Weaver DL, et al. American Society of Clinical Oncology Clinical Practice. Sentinel lymph node biopsy for patients with early-stage breast cancer: American Society of Clinical Oncology clinical practice guideline update. J Clin Oncol. 2014; 32(13):1365-83.

22. NCCN Clinical Practice Guidelines in Oncology. Breast Cancer Version 3.2017, http://www.nccn.org/professionals/physician_gls/pdf/breast.pdf (06 Jan 2018, date last accessed)

23. Mamounas EP, Anderson SJ, Dignam JJ, Bear HD, Julian TB, Geyer Jr CE, et al. Predictors of locoregional recurrence after neoadjuvant chemotherapy: results from combined analysis of National Surgical Adjuvant Breast and Bowel Project B-18 and B-27. J Clin Oncol. 2012;30(32):3960-6.

24. Kelly AM, Dwamena B, Cronin P, Carlos RC. Breast cancer sentinel node identifcation and classifcation after neoadjuvant chemotherapy-systematic review and meta analysis. Acad Radiol. 2009;16(5):551-63.

25. Brennan ME, Turner RM, Ciatti S, Marinovich ML, French JR, Macaskill P, et al. Ductal carcinoma in situ at core-needle biopsy: meta-analysis of underestimation and predictors of invasive breast cancer. Radiology. 2011; 260(1):119-28

26. Mamounas EP, Kuehn T, Rutgers EJT, von Minckwitz G. Current approach of the axilla in patients with early-stage breast cancer. Lancet. 2017;S01406736(17)31451-4. Online ahead of print.

27. Schneider C, Trocha S, McKinley B, Shaw J, Bielby S, Blackhurst D, et al: The use of sentinel lymph node biopsy in ductal carcinoma in situ. Am Surg. 2010;76(9):943-6

28. Moody LC, Wen X, McKnight T, Chao C. Indications for sentinel lymph node biopsy in multifocal and multicentric breast cancer. Surgery. 2012; 152(3):389-96

29. Borgstein PJ, Meijer S, Pijpers RJ, van Diest PJ. Functional lymphatic anatomy for sentinel lymph node biopsy in breast cancer: echo from the past and periareolar blue method. Ann Surg. 2000;232(1):81-9.
30. McMaster KM, Wong SL, Martin RC, Chao C, Tuttle TM, Noyes RD, et al. Dermal injection of radioactive colloid is superior to peritumoral injection for breast cancer sentinel lymph node biopsy: results of a multiinstitutional study. Ann Surg. 2001; 233(5):676-87.

31. Schrenk $P$, Wayand $W$. Sentinel-node biopsy in axillary lymph-node staging for patients with multicentric breast cancer. Lancet. 2001;357(9250):122.

32. Kern KA. Concordance and validation study of sentinel lymph node biopsy for breast cancer using subareolar injection of blue dye and technetium 99m sulfur colloid. J Am Coll Surg. 2002;195(4):467-75.

33. Knauer M, Konstantiniuk P, Haid A, Wenzl E, Riegler-Keil M, Pöstlberger S, et al. Multicentric breast cancer: a new indication for sentinel lymph node biopsy - a multi-institutional validation study. J Clin Oncol. 2006;24(21): 3374-80.

34. Dupont EL, Kuhn MA, McCann C, Salud C, Spanton JL, Cox CE. The role of sentinel lymph node biopsy in women undergoing prophylactic mastectomy. Am J Surg. 2000;180(4):274-7.

35. Lowery AJ, Kell MR, Glynn RW, Kerin MJ, Sweeney KJ. Locoregional recurrence after breast cancer surgery: a systematic review by receptor phenotype. Breast Cancer Res Treat 2012;133:831-41.

36. Galimberti V, Cole BF, Zurrida S, Viale G, Luini A, Veronesi P et al. International Breast Cancer Study Group Trial 23-01 investigators. Axillary dissection versus no axillary dissection in patients with sentinel-node micrometastases (IBCSG 23-01): a phase 3 randomised controlled trial. Lancet Oncol. 2013 Apr;14(4):297-305.

37. Maaskant-Braat AJ, Voogd AC, Roumen RM, Nieuwenhuijzen GA. Repeat sentinel node biopsy in patients with locally recurrent breast cancer: a systematic review and meta-analysis of the literature. Breast Cancer Res Treat. 2013;138(1):13-20.

38. Lyman GH, Giuliano AE, Somerfield MR, Benson 3rd Al B, Bodurka DC, Burstein HJ, et al. American Society of Clinical Oncology guideline recommendations for sentinel lymph node biopsy in early-stage breast cancer. J Clin Oncol. 2005;23(30):7703-20.

39. Hidar S, Bibi M, Gharbi O, Tebra S, Trabelsi A, Korbi S, et al. Sentinel lymph node biopsy after neoadjuvant chemotherapy in inflammatory breast cancer. Int J Surg. 2009;7(3): 272-5

40. Chung MH, Ye W, Giuliano AE. Role for sentinel lymph node dissection in the management of large (> or $=5 \mathrm{~cm}$ ) invasive breast cancer. Ann Surg Oncol. 2001;8(9):688-92.

41. Wong SL, Chao C, Edwards MJ, Tuttle TM, Noyes RD, Carlson DJ, et al. Accuracy of sentinel lymph node biopsy for patients with T2 and T3 breast cancers. Am Surg. 2001; 67(6):522-6; discussion 527-8.

42. Harlow SP, Weaver DL. Overview of sentinel lymph node biopsy in breast cancer. UpToDate, 2nd of October 2017.

43. Borgstein PJ, Pijpers R, Comans EF, van Diest PJ, Boom RP, Meijer S. Sentinel lymph node biopsy in breast cancer: guidelines and pitfalls of lymphoscintigraphy and gamma probe detection. J Am Coll Surg. 1998; 186(3):275-83

44. Giuliano AE, McCall L, Beitsch P, Whitworth PW, Blumencranz P, Leitch AM, et al. Locoregional recurrence after sentinel lymph node dissection with or without axillary dissection in patients with sentinel lymph node metastases: the American College of Surgeons Oncology Group Z0011 randomized trial. Ann Surg. 2010;252(3):426-32; discussion 432-3.

45. Nottegar A, Veronesse N, Senthil M, Roumen RM, Stubbs B, Choi AH, et al. Extra-nodal extension of sentinel lymph node metastases is a marker of poor prognosis in breast cancer patients: A systematic review and an exploratory meta-analysis. Eur J Surg Oncol 2016;42(7):919-25.

46. Fellegara G, Carcangiu ML, Rosai J. Benign epithelial inclusions in axillary lymph nodes: report of 18 cases and review of the literature. Am J Surg Pathol. 2011;35(8):1123-33.

47. Gooch J, King TA, Eaton A, Dengel L, Stempel M, Corben AD, et al. The extent of extracapsular extension may influence the need for axillary lymph node dissection in patients with T1-T2 breast cancer. Ann Surg Oncol. 2014; 21(9):2897-903.

48. Choi AH, Blount S, Perez MN, Chavez de Paz CE, Rodriguez SA, Surrusco M, Garberoglio CA, Lum SS, Senthil M. Size of Extranodal Extension on Sentinel Lymph Node Dissection in the American College of Surgeons Oncology Group Z0011 Trial Era. JAMA Surg. 2015;150(12):1141-8. 
49. Dordea M, Colvin H, Cox P, Pujol Nicolas A, Kanakala V, Iwuchukwu 0. Clinical and histopathological factors affecting failed sentinel node localization in axillary staging for breast cancer. Surgeon 2013;11(2):63-6.

50. Goyal A, Newcombe RG, Chhabra A, Mansel RE; ALMANAC Trialists Group. Factors affecting failed localisation and false-negative rates of sentinel node biopsy in breast cancer-results of the ALMANAC validation phase. Breast Cancer Res Treat. 2006;99(2):203-8.

51. Giuliano AE, Hunt KK, Ballman KV, Beitsch PD, Whitworth PW, Blumencranz PW et al. Axillary dissection vs no axillary dissection in women with invasive breast cancer and sentinel node metastasis: a randomized clinical trial. JAMA 2011;305(6):569-75.

52. NABON national guideline breast cancer 2.0. Comprehensive Cancer Centre Netherlands; 2012. Available at: www.oncoline.nl/ mammacarcinoom.

53. James TA, Coffman AR, Chagpar AB, Boughey JC, Klimberg VS, Morrow M, et al. Troubleshooting Sentinel Lymph Node Biopsy in Breast Cancer Surgery. Ann Surg Oncol. 2016;23(11):3459-3466.

54. Madsen EV, Aalders KC, van der Heiden-van der Loo M, Gobardhan PD, van Oort PM, van der Ent FW, et al. Prognostic Significance of Tumor-Positive Internal Mammary Sentinel Lymph Nodes in Breast Cancer: A Multicenter Cohort Study. Ann Surg Oncol. 2015;22(13):4254-62.

55. Sugg SL, Ferguson DJ, Posner MC, Heimann R. Should internal mammary nodes be sampled in the sentinel lymph node era? Ann Surg Oncol. 2000; 7(3):188-92.

56. Cheon H, Kim HJ, Lee SW, Kim DH, Lee CH, Cho SH, et al. Internal mammary node adenopathy on breast MRI and PET/CT for initial staging in patients with operable breast cancer: prevalence and associated factors. Breast Cancer Res Treat. 2016 Dec;160(3):523-530.

57. Young Koo M, Kyung Lee S, Youn Bae S, Choi MY, Hui Cho D, Kim S, et al. Long-Term Outcome of Internal Mammary Lymph Node Detected by Lymphoscintigraphy in Early Breast Cancer. J Breast Cancer. 2012;15(1): 98-104.

58. Ozmen V, Ozcinar B, Bozdogan A, Eralp Y, Yavuz E, Dincer M.The effect of internal mammary lymph node biopsy on the therapeutic decision and survival of patients with breast cancer. Eur J Surg Oncol. 2015;41(10): 1368-72.

59. Harris EE, Hwang WT, Seyednejad F, Solin LJ. Prognosis after regional lymph node recurrence in patients with stage I-II breast carcinoma treated with breast conservation therapy. Cancer. 2003;98(10):2144-51.

60. Jansen L, Doting MH, Rutgers EJ, de Vries J, Olmos RA, Nieweg OE. Clinical relevance of sentinel lymph nodes outside the axilla in patients with breast cancer. Br J Surg. 2000;87(7):920-5.
61. Poortmans PM, Collette S, Kirkove C, Van Limbergen E, Budach V, Struikmans $\mathrm{H}$, et al. Internal mammary and medial supraclavicular irradiation in breast cancer. N Engl J Med. 2015;373(4):317-27.

62. Jochelson MS, Lebron L, Jacobs SS, Zheng J, Moskowitz CS, Powell SN, et al. Detection of Internal Mammary Adenopathy in Patients With Breast Cancer by PET/CT and MRI. AJR Am J Roentgenol. 2015;205(4): 899-904.

63. Derkx F, Maaskant-Braat AJ, van der Sangen MJ, Nieuwenhuiizen GA, van de Poll-Franse LV, Roumen RM, et al. Staging and management of axillary lymph nodes in patients with local recurrence in the breast or chest wall after a previous negative sentinel node procedure. Eur J Surg Oncol 2010; 36:646-51.

64. Rosen PP. The Pathology of Axillary and Intramammary Lymph Nodes. In Rosen's Breast Pathology, 3rd Edition, ed. Lippincott Williams \& Wilkins; 2009. p. 1067-1085.

65. Moinfar F. Specimen Processing. In Essentials of Diagnostic Breast Pathology. A Practical Approach, ed. Berlin Heidelberg: Springer-Verlag; 2007. p. 11-12.

66. Chen YZ, Zhang JX, Chen JJ, Liu ZB, Huang XY, Yi Cheng J, et al. Factors associated with the misdiagnosis of sentinel lymph nodes using touch imprint cytology for early stage breast cancer. Oncol Lett. 2011;2(2): 277-281.

67. Poling JS, Tsangaris TN, Argani P, Cimino-Mathews A. Frozen section evaluation of breast carcinoma sentinel lymph nodes: a retrospective review of 1,940 cases. Breast Cancer Res Treat. 2014;148(2):355-361.

68. Tille JC, Egger JF, Devillaz MC, Vlastos G, Pelte MF. Frozen section in axillary sentinel lymph nodes for diagnosis of breast cancer micrometastasis. Anticancer Res. 2009;29(11):4711-6.

69. van der Noordaa MEM, Vrancken Peeters MTFD, Rutgers EJT. The intraoperative assessment of sentinel nodes - Standards and controversies. Breast. 2017, 34 Suppl 1:S64-S69.

70. Sanders ME, Simpson JF. Sentinel Lymph Node. In Breast pathology, ed. New York: Demos Medical; 2014. p. 260-261.

71. Bhargava R, Esposito NN, Dabbs DJ. Immunohistology of the Breast. In Diagnostic immunohistochemistry, 3rd Edition. Philadelphia: Elsevier; 2010. p. 787-790.

72. Huston TL, Osborne MP. Evaluating and Staging the Patient with Breast Cancer. In Breast cancer. 2nd Edition. Philadelphia: Elsevier; 2005. p. 309-312.

73. Badve S, Dabbs DJ. Sentinel Lymph Node Biopsy. In Breast pathology. Philadelphia: Elsevier; 2012. p. 93-102. 